Life Sciences Contribution

Royal Ontario Museum

A Revision of the Latipinnate Ichthyosaurs of the Lower Jurassic of England (Reptilia: Ichthyosauria)

C. McGowan

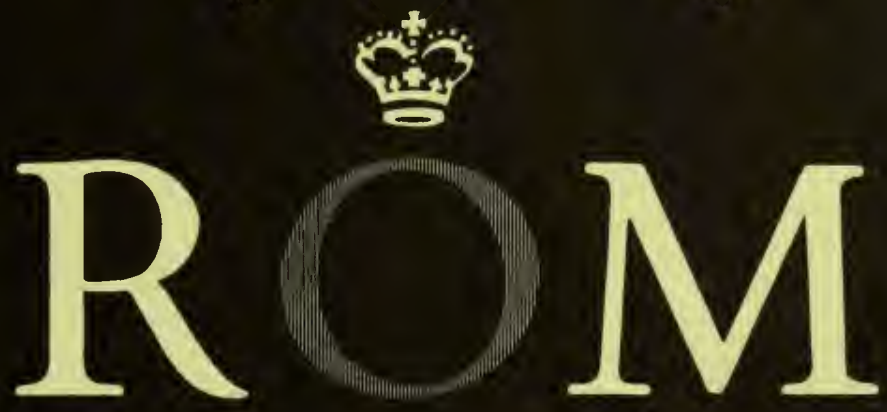


Digitized by the Internet Archive in 2011 with funding from University of Toronto 
LIFE SCIENCES CONTRIBUTIONS

ROYAL ONTARIO MUSEUM

NUMBER 100

c. McGowan A Revision of the Latipinnate Ichthyosaurs of the Lower Jurassic of England (Reptilia: Ichthyosauria)

Publication date 6 December 1974

ISBN 0-88854-165-1

Suggested citation: Life Sci. Contr., R. Ont. Mus. 


\section{ROYAL ONTARIO MUSEUM PUBLICATIONS IN LIFE SCIENCES}

The Royal Ontario Museum publishes three series in the Life Sciences:

LIFE SCIENCES CONTRIBUTIONS, a numbered series of original scientific publications, including monographic works.

LIFE SCIENCES OCCASIONAL PAPERS, a numbered series of original scientific publications, primarily short and usually of taxonomic significance.

LIFE SCIENCES MISCELLANEOUS PUBLICATIONS, an unnumbered series of publications of varied subject matter and format.

All manuscripts considered for publication are subject to the scrutiny and editorial policies of the Life Sciences Editorial Board, and to review by persons outside the Museum staff who are authorities in the particular field involved.

\section{LIFE SCIENCES EDITORIAL BOARD}

Chairman: WALTER M. TOVELL

Editor: J. C. BARLOW

Associate Editor: A. R. EMERY

Associate Editor: D. W. BARR

Christopher mcGowan is Associate Curator, Department of Vertebrate Palaeontology, Royal Ontario Museum, and Assistant Professor, Department of Zoology, University of Toronto.

PRICE : $\$ 1.50$

(C) The Royal Ontario Museum, 1974

100 Queen's Park, Toronto, Canada

PRINTED AT THE UNIVERSITY OF TORONTO PRESS 


\title{
A Revision of the Latipinnate Ichthyosaurs of the Lower Jurassic of England (Reptilia: Ichthyosauria)
}

\begin{abstract}
A study of 60 latipinnate ichthyosaurs from the English Lower Lias (Lower Jurassic) reveals only four valid species; Ichthyosaurus communis Conybeare, I. breviceps Owen, I. conybeari Lydekker, and I. tenuirostris Conybeare. Emended diagnoses and descriptions are given. I. communis, a medium-sized ichthyosaur reaching a maximum length of about $2.5 \mathrm{~m}$, is the commonest species. I. tenuirostris, of similar size to 1 . communis, is less common and characterized by extreme snout length. I. breviceps, a small species with a maximum recorded body length of $1.3 \mathrm{~m}$, is scarce and is characterized by an abbreviated snout. The rarest latipinnate is $I$. conybeari, with only two individuals known. Both are small, with an estimated body length of $1.3 \mathrm{~m}$ in the larger individual. The snout is long, slender, and sharply pointed, and the orbit appears to be relatively large.
\end{abstract}

\section{Zusammenfassung}

Eine Studie über 60 latipinnate Ichthyosaurier aus dem englischen unteren Lias (Unterer Jura) ergibt nur vier gültige Arten; Ichthyosaurus communis Conybeare, I. breviceps Owen, I. conybeari Lydekker, I. tenuirostris Conybeare. Verbesserte Diagnosen und Beschreibungen werden gegeben. $I$. communis, die gewöhnlichste Art, ist ein mittelgrosser Ichthyosaurier, welcher eine Länge von ungefähr 2.5 Meter erreicht. I. tenuirostris, von ungefähr derselben Grösse wie I. communis, ist seltener und zeichnet sich durch seine ungewöhnlich lange Schnauze aus. I. breviceps, eine kleine Art, mit einer Länge bis zu 1.3 Meter, ist sehr selten und zeichnet sich durch seine verkürzte Schnauze aus. Die seltenste Art ist I. conybeari, von welcher nur zwei Exemplare bekannt sind. Beide sind klein, das grössere Exemplar hat eine abgeschätzte Länge von 1.3 Meter. Die Schnauze ist lang, schmal, scharf zugespitzt, und die Augenhöhlen scheinen verhältnismässig gross zu sein.

\section{Introduction}

The majority of known ichthyosaur skeletons have been collected from the Lower Jurassic of Europe, principally from the Lower Lias (Hettangian to Sinemurian) of western England and the Upper Lias (Lower Toarcian) of southwestern Germany. Latipinnates predominate in the English Lower Lias, 
but the Upper Liassic ichthyosaurs appear to be exclusively longipinnates (McGowan, 1972a, 1972b). The present study is confined to the Lower Liassic latipinnates, all of which are referred to a single genus, Ichthyosaurus (see McGowan, 1974).

The systematics of the Lower Liassic latipinnates is confused because descriptions are generally inadequate and often based upon non-diagnostic material such as isolated teeth and vertebral centra. Allometric growth is seldom taken into account, although Owen referred to this phenomenon when discussing Ichthyosaurus breviceps: "The specific characters are more fully exemplified in specimens of the skull of larger individuals, which show that the proportions of the rostrum to the rest of the skull in the smaller skeleton may be due to nonage ..." (1881, p. 109). Lydekker (1889, p. 13) treats 12 latipinnate species, the majority erected upon inadequate material. As four of these 12 species are from the Lower Lias of England: I. breviceps Owen, 1881, I. conybeari Lydekker, 1888, I. communis Conybeare, 1821 and I. intermedius Conybeare, 1822, they are of interest here.

The original diagnoses for I. breviceps and I. conybeari, although somewhat inadequate, were based upon reliable characters. The original diagnoses for I. communis and I. intermedius, however, were based upon tooth morphology, and the relative lengths of the angular and surangular, characters I have found to be unreliable. The teeth of Lower Jurassic ichthyosaurs are straight or gently curved cones with longitudinal striations on the base and crown. Some teeth are stout, others, especially towards the tip of the snout, are slender. The longitudinal striations range from faint lines to prominent ridges. It is often possible to observe the whole range of dental variations within the same dentition. Almost all dentitions have at least some teeth corresponding to Conybeare's figure for I. communis (1822, pl. 15, fig. 8). Further, of several thousand Liassic teeth I have now examined, less than ten correspond with Conybeare's figure for I. intermedius (1822, pl. 15, fig. 9) and these belong to only two specimens (R44 in the British Museum, J35183, in the Oxford University Museum). The relative extent of the angular and surangular could be determined in less than half of the specimens examined and in only two of these did the angular extend further forward than the surangular (43971 and R1157, both in the British Museum). The present study is an attempt to overcome these inadequacies and bring order and stability to the systematics of the Liassic latipinnates. 


\section{Materials and Methods}

Data were obtained from 66 latipinnate or presumed latipinnate ichthyosaurs, all from the Lower Lias (Hettangian and Sinemurian) of England. The abbreviations used for the collections examined are: BMNH, British Museum (Natural History); IGS, Institute of Geological Sciences, London; ouM, Oxford University Museum; scC, Street Collection in the care of Clarks Shoe Company, Street, Somerset; sCM, Somerset County Museum, Taunton, Somerset; and SMC, Sedgwick Museum, Cambridge University.

The state of preservation of these specimens was generally good, more than half being complete or near complete skeletons. All measurements were made with vernier calipers accurate to $0.01 \mathrm{~cm}$, except those of body length which were taken with a tape accurate to $0.1 \mathrm{~cm}$. Details of characters are given elsewhere (McGowan, 1974), and those which have been found to be of systematic importance are: length of jaw, length of snout, length of premaxillary segment, length of prenarial segment, diameter of orbit, internal diameter of sclerotic ring, length of external naris, number of maxillary teeth, length of forefin, width of forefin, number of primary digits (see

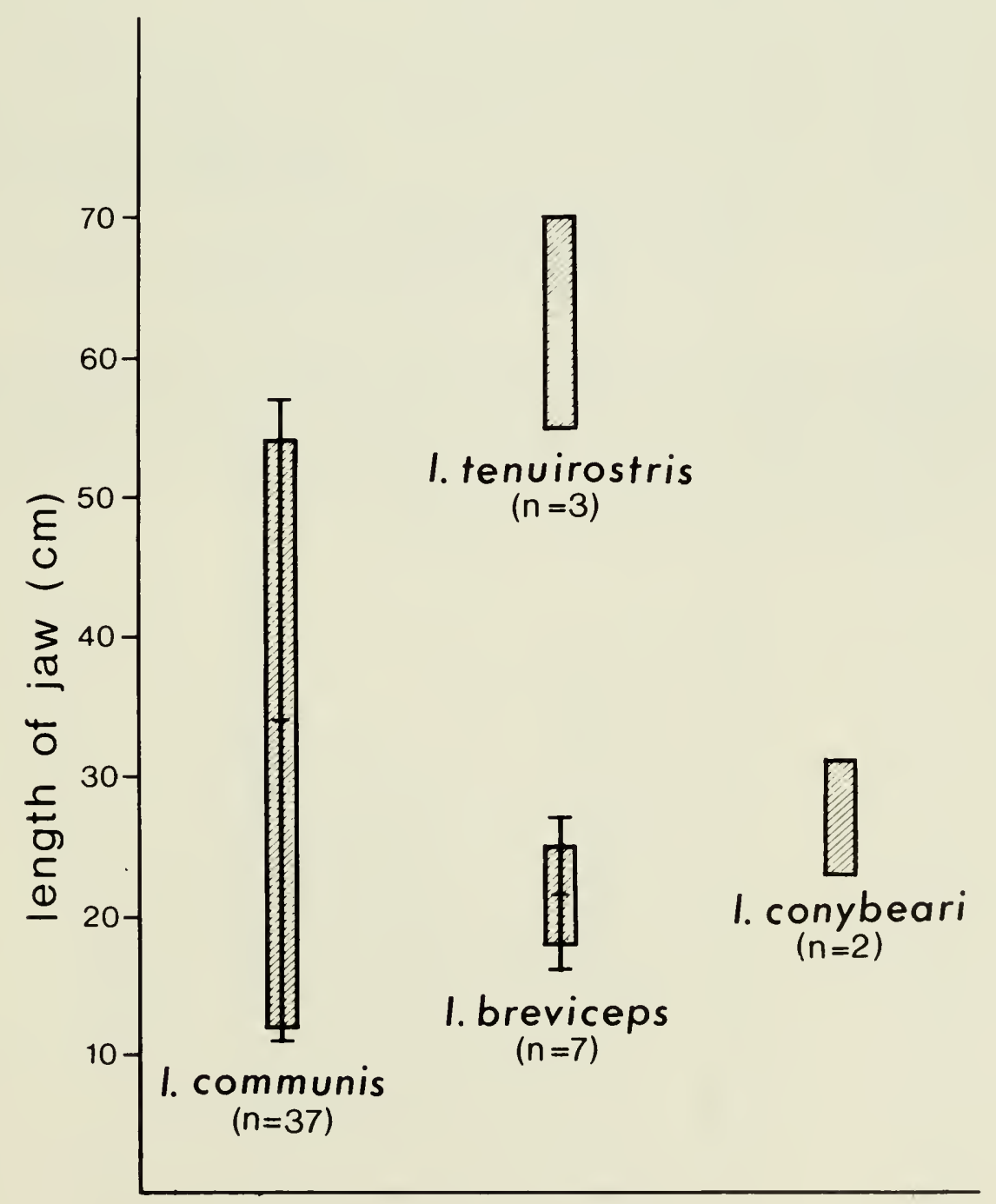

Fig. 1 Size ranges of Ichthyosaurus communis, I. conybeari, I. breviceps and I. tenuirostris based on jaw lengths.

Solid box - observed range, bar - 95 per cent confidence limits. 
McGowan, 1972a), total digital count, maximum number of elements in longest digit, occurrence of notching in forefin elements, vertebral count from skull to tail bend, and vertebral count from skull to pelvis.

Because of size variation in the sampled specimens it was necessary to convert the continuous variates into ratios. The cranial ratios used are: diameter of orbit to length of jaw, length of snout to length of jaw, length of premaxillary segment to length of jaw, length of prenarial segment to length of jaw, length of external naris to diameter of orbit, and internal diameter of sclerotic ring to diameter of orbit. The forefin ratio used is the aspect ratio, length of forefin to width of forefin.

Using the above-mentioned characters, four distinct groups were established. Before testing their statistical significance, however, it was necessary to determine (a) whether the selected variates were normally distributed, and (b) whether they were affected by allometric growth. Because of small sample sizes, analyses could be conducted on only two of the four groups. The statistics $\mathrm{g}_{1}$ and $\mathrm{g}_{2}$, for measuring skewness and kurtosis respectively were generated for each character within each group (see Sokal \& Rohlf, 1969) using the computer programme UNIVAR. No characters departed significantly from a normal distribution. An analysis of allometric growth, given elsewhere (McGowan, 1973) shows growth to be largely isometric. Hence the ratios used here are largely unaffected by the size of the individual.

A Students t-test was used to make pairwise tests of the differences among group means for each character (see Simpson et al., 1960, p. 176) using the computer programme TTEST. Probabilities are designated accordingly: $\mathrm{P}<0.001$ as $* * *, 0.01>\mathrm{P}>0.001$ as $* *, 0.05>\mathrm{P}>0.01$ as *. Programmes UNIVAR and TTEST available at ROM.

\section{Results}

Four latipinnate species were recognized in the English Lower Lias, Ichthyosaurus communis Conybeare, I. breviceps Owen, I. conybeari Lydekker, and I. tenuirostris Conybeare. Results of the statistical analyses are shown in Tables 1 and 2, and their size ranges are shown in Fig. 1. 

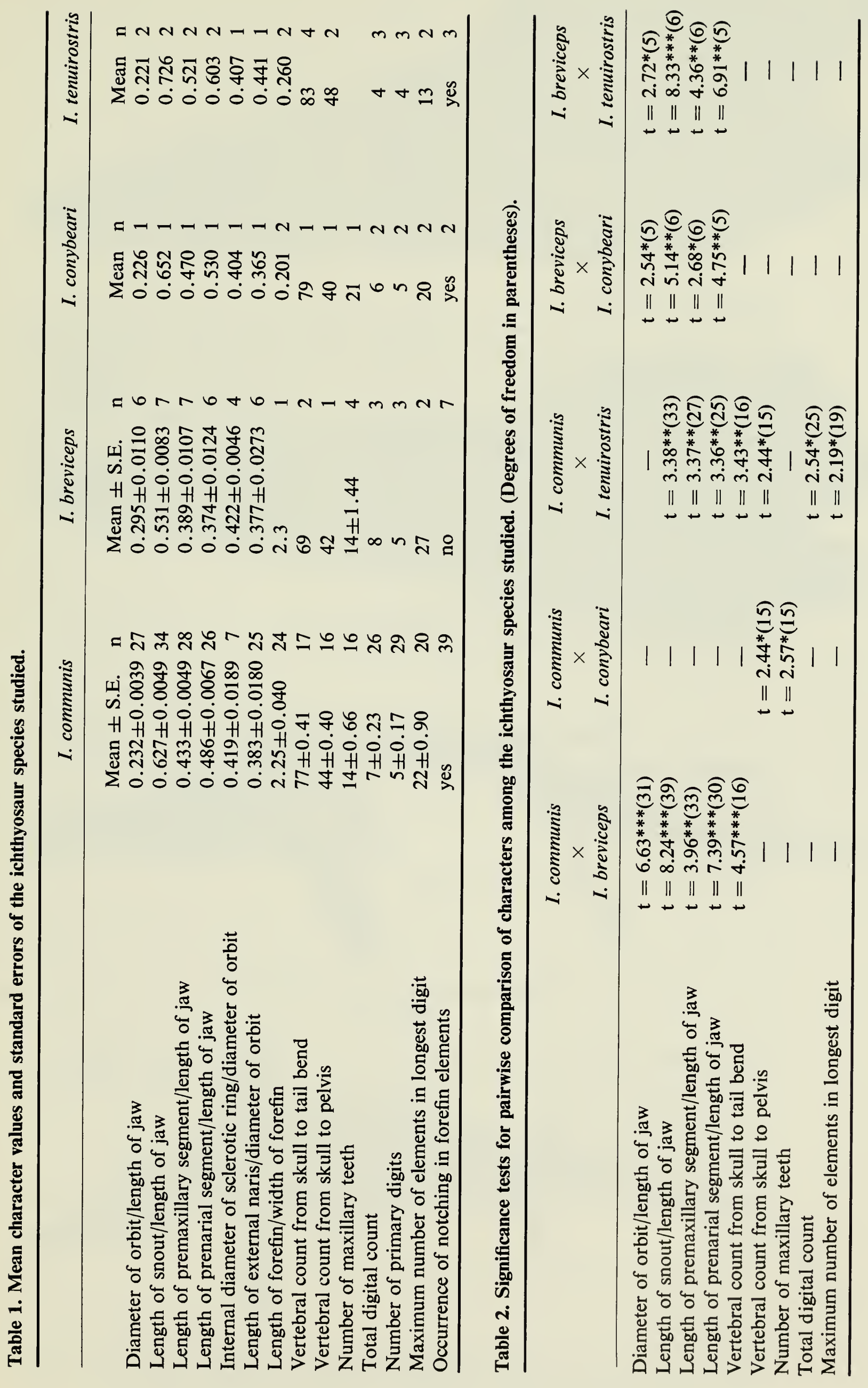


\section{Class Reptilia}

Subclass Euryapsida(?)

Order Ichthyosauria

Suborder Latipinnati Von Huene, 1948

\section{Family Ichthyosauridae Bonaparte 1841}

\section{Emended Diagnosis}

Forefin with no fewer than four primary digits, two of which originate from intermedium; total digital count usually not less than five; orbit relatively large, ratio, diameter of orbit to length of jaw $>0.20$; aperture of the sclerotic ring relatively large, ratio, internal diameter of sclerotic ring to diameter of orbit usually $>0.35$; maxilla relatively small, ratio, length of premaxillary segment to length of jaw usually $>0.40$; pelvic girdle tripartite, rib articulations predominantly bicipital; Liassic in age and largely, if not wholly, confined to the Lower division (Hettangian and Sinemurian).

\section{Type Genus}

Ichthyosaurus De La Beche \& Conybeare, 1821.

Ichthyosaurus Koenig, 1818 nomen nudum.

\section{Ichthyosaurus De La Beche \& Conybeare, 1821}

\section{Emended Diagnosis}

Same as that for family.

\section{Type Species}

Ichthyosaurus communis Conybeare

\section{Ichthyosaurus communis Conybeare}

Figs. 2-3

Ichthyosaurus communis De La Beche \& Conybeare, 1821, p. 594.

Ichthyosaurus communis Conybeare, Conybeare, 1822, p. 108, pl. 15, fig. 8; pl. 16, fig. 8.

Ichthyosaurus intermedius Conybeare, 1822, p. 108, pl. 17.

Ichthyosaurus chiroparamekostinus Hawkins, 1834, pl. 17, pl. 22.

Ichthyosaurus chiroparamekostinus Hawkins, Hawkins, 1840, pl. 17, pl. 20, pl. 21.

Ichthyosaurus latimanus Owen, 1840, p. 123.

Ichthyosaurus communis Conybeare, Owen (pro-parte), 1881, p. 111, pl.

30, fig. 3.

Ichthyosaurus intermedius Conybeare, Owen, 1881, p. 113, pl. 30, fig. 1.

Ichthyosaurus communis Conybeare, Lydekker, 1889, p. 41.

Ichthyosaurus intermedius Conybeare, Lydekker, 1889, p. 55. 

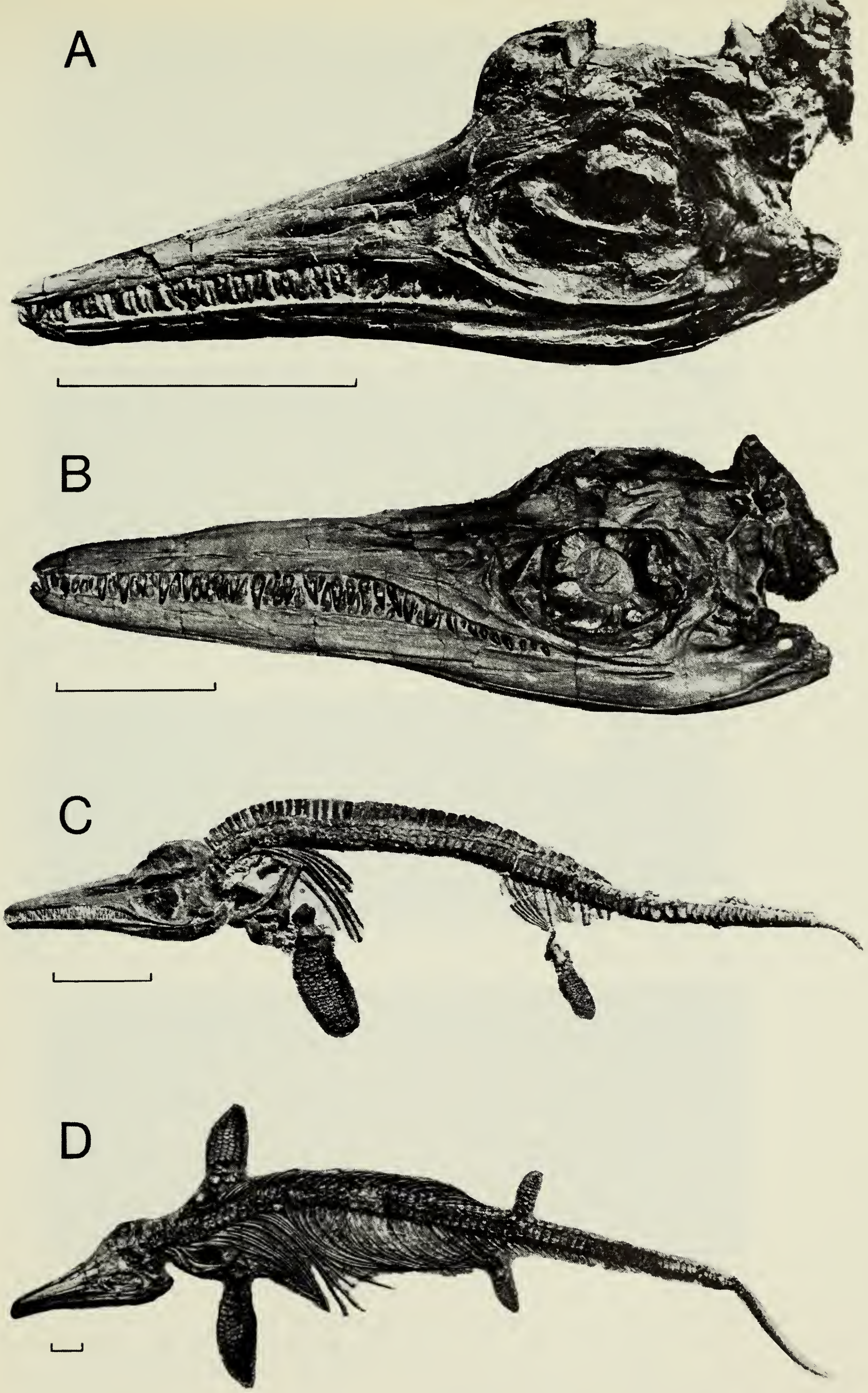

Fig. 2 Ichthyosaurus communis Conybeare, scale $=10 \mathrm{~cm}$.

A. BMNH R1162, skull of proposed neotype, Lower Lias, Lyme Regis.

B. BMNH 39492, entire, Lower Lias, Lyme Regis.

C. BMNH R1073, entire, Lower Lias, Lyme Regis.

D. BMNH 2013, entire, Łower Lias, Street (photograph laterally inverted). 

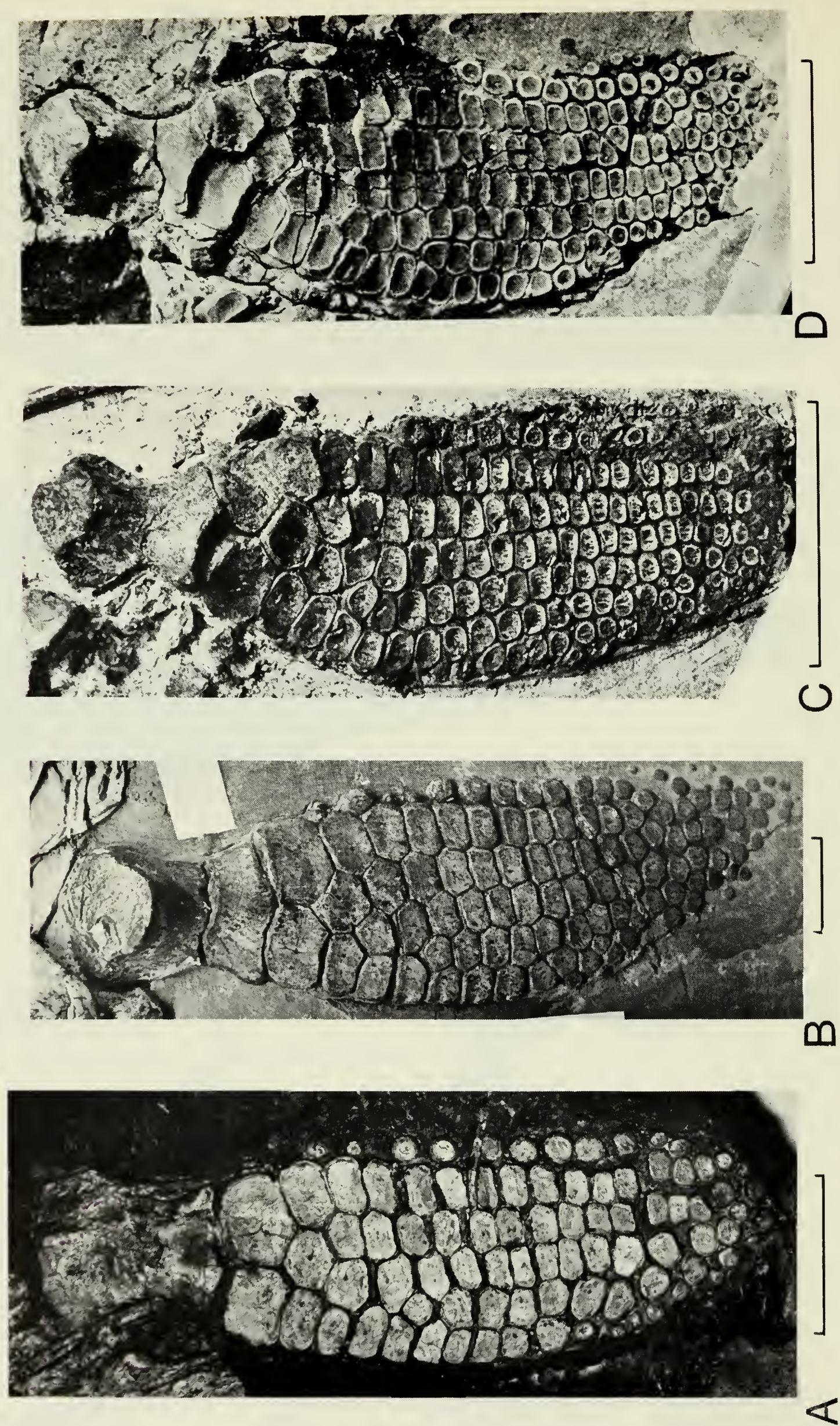

Fig. 3 Ichthyosaurus communis Conybeare, scale $=5 \mathrm{~cm}$.

Comparison of forefins of geologically older specimens, from Street (A, B) with those of geologically younger specimens from Lyme Regis (C, D)

A. SCC 15, Lower Lias, Street.

B. BMNH 2013, Lower Lias, Street.

C. BMNH R1073, Lower Lias, Lyme Regis.

D. BMNH R 1162 (proposed neotype), Lower Lias, Lyme Regis. 
Eurypterygius communis (Conybeare), Von Huene (pro-parte), 1922, p. 5. Eurypterygius intermedius (Conybeare), Von Huene, 1922, p. 9, pl. 1, fig. 5.

\section{Emended Diagnosis}

Vertebral count to tail bend $77 \pm 2$; vertebral count to pelvis $44 \pm 3$ but usually $<46$; ratio, diameter of orbit to length of jaw $0.20-0.28$ but usually $<0.25$; ratio, length of snout to length of jaw $0.57-0.69$; ratio, length of premaxillary segment to length of jaw $0.38-0.48$ but usually exceeding 0.40 ; ratio, length of prenarial segment to length of jaw $0.40-0.56$ but usually exceeding 0.43 ; internal diameter of sclerotic ring to diameter of orbit usually $>0.35$; maxillary teeth $14 \pm 4$; primary digits $\geqslant 4$; elements in longest digit

$\geqslant 17$; notching may occur in fore- or hindfin elements.

\section{Original Type Material}

A partial skeleton from Lyme Regis, Dorset, briefly described by Conybeare 1821 , p. 594, now lost (see Remarks).

\section{Proposed Neotype}

BMNH R1162, an almost complete skeleton in the British Museum (Natural History), London.

\section{Consistency of Neotype with Original Type-Material}

The original type-material was found at Lyme Regis, and since only the lower division of the Lias outcrops there, it is certain that the specimen was Lower Liassic in age (the tooth figured by Conybeare in 1822 was also from the Lias, probably from Lyme Regis). It is reasonably certain that the specimen was not a longipinnate because all the known longipinnates are much larger than Conybeare's (1821) specimen. Conversely, Conybeare's specimen is too large to be referred to I. breviceps or I. conybeari. No other latipinnates occur at Lyme Regis. The proposed neotype is from Lyme Regis, and the jaw size of Conybeare's (1821) specimen falls within the size range of the taxon which includes the neotype. The proposed neotype is therefore consistent with what is known of the original type-material. (It is also consistent with Conybeare's figure of the tooth of I. communis, 1822, pl. 15, fig. 8).

\section{Other Material}

From the 39 specimens which I refer to this species may be cited those which have contributed most to the emended description:

A. From Lyme Regis, Dorset: BMNH R1073, вMNH 36256, BMNH R12, BMNH R1071, BMNH 39492. The first three are almost complete skeletons, the fourth has some post-cranial structures including a forefin, and the fifth is a particularly well-preserved skull.

B. From Street, Somerset: вMNн 2013, вмNн 2013a, вMNH R44, вмNH 14565, SMC J35183, SMC J59575. All are complete or nearly complete skeletons. BMNH 2013 is particularly well preserved and probably the finest latipinnate specimen from the Lower Lias. 


\section{Locality and Horizon}

I. communis is known from Lyme Regis in Dorset, Street in Somerset, and Barrow-on-Soar in Leicestershire. As noted elsewhere (McGowan, 1974) the geological range of ichthyosaurs collected from Lyme Regis may be taken to be from the ammonite zones of Schlotheimia angulata to Arnioceras semicostatum (Upper Hettangian - Lower Sinemurian), Fig. 4. The Somerset locality is slightly older (geologically) than the Dorset locality. The horizon exposed at the old quarry of Street was of the ammonite zone of Psiloceras planorbis, and Arkell (1933) noted that most of the reptiles were collected from the Pre-planorbis beds which are at the base of this zone (Lower Hettangian). There is, therefore, a small temporal separation between the two localities, represented by the zone of Psiloceras planorbis.

\section{Emended Description}

I. communis, the commonest Liassic latipinnate was a medium-sized species, reaching a total length of about $2.5 \mathrm{~m}$. The small differences between the Dorset specimens and those from the geologically older Somerset locality are in the forefin and are consistent with the evolutionary trends discussed elsewhere (McGowan, 1972b).

\section{SKULL}

Snout, which constitutes over half the length of skull, tapers gently towards tip. Mean value for ratio, length of snout to length of jaw $0.63,0.59$ in neotype. Maxilla short, wedge-shaped, bearing no more than 18 teeth. Ratio, length of maxillary segment to length of jaw 0.41 in neotype, mean 0.43 . External narial aperture (frequently indistinct) bounded by lachrymal, premaxilla, and nasal. Orbit fairly large, ratio, diameter of orbit to length of jaw $>0.20,0.25$ in neotype, mean 0.23 .

\begin{tabular}{|c|c|c|c|}
\hline STAGES & ZONES & $\begin{array}{l}\text { LITHOLOGICAL. } \\
\text { FORMATIONS }\end{array}$ & LOCALITIES \\
\hline \multirow{6}{*}{ 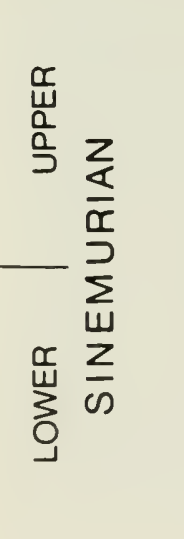 } & Echioceras raricostatum & \multirow{4}{*}{$\begin{array}{l}\text { Black Marl of } \\
\text { Black Ven }\end{array}$} & \multirow{8}{*}{$\begin{array}{c}\text { Lyme Regis } \\
\text { Dorset }\end{array}$} \\
\hline & Oxynoticeras oxynotum & & \\
\hline & Asteroceras obtusum & & \\
\hline & Caenisites turneri & & \\
\hline & Arnioceras semicostatum & Shales-with-"Beef" & \\
\hline & Arietites bucklandi & \multirow{4}{*}{ Blue Lias } & \\
\hline \multirow{3}{*}{ 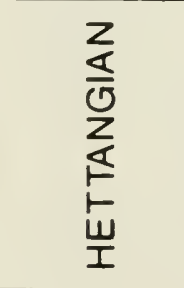 } & Schlotheimia angulata & & \\
\hline & Alsatites liasicus & & \\
\hline & Psiloceras planorobis & & $\begin{array}{c}\text { Street } \\
\text { Somerset }\end{array}$ \\
\hline
\end{tabular}

Fig. 4 The ammonite zones of the English Lower Lias (from McGowan, 1974). 


\section{FOREFIN}

In Somerset specimens forefin is rectangular rather than rounded (Fig. 3A, $\mathrm{B})$; individual elements tend to be pentagonal or hexagonal rather than discoidal and are fewer in number, with not more than 20 elements in longest digit. Notching usually occurs in some elements of first digit, no notching in Dorset material. Number of primary digits not exceeding five in Somerset specimens, but usually six or seven in Dorset material. In neotype (BMNH R1162), from Dorset, forefin has rounded outline, possesses six primary digits, with 26 elements in the longest digit (Fig. 3D). Forefin structure quite variable within species with wide range of variation, both in number of digits and elements, and in their spatial configuration. This plasticity is exemplified in a skeleton from Somerset (oum J13799) where left fin is quite distinct from right (Fig. 5).

\section{AXIAL SKELETON}

Vertebral count to tail bend 77 in the neotype, mean value 77 , observed range 74-79. Total vertebral count indeterminate in the neotype, but mean value approximately 135 . Height of neural arch and spine relative to centrum somewhat less than in I. breviceps, but this is not a reliable character because vertebral proportions vary according to position in column. Neural arch and spine become relatively taller with increasing distance from skull, reach a maximum in posterior thoracic region, then gradually decrease in height until they disappear at some point distal to tail bend.

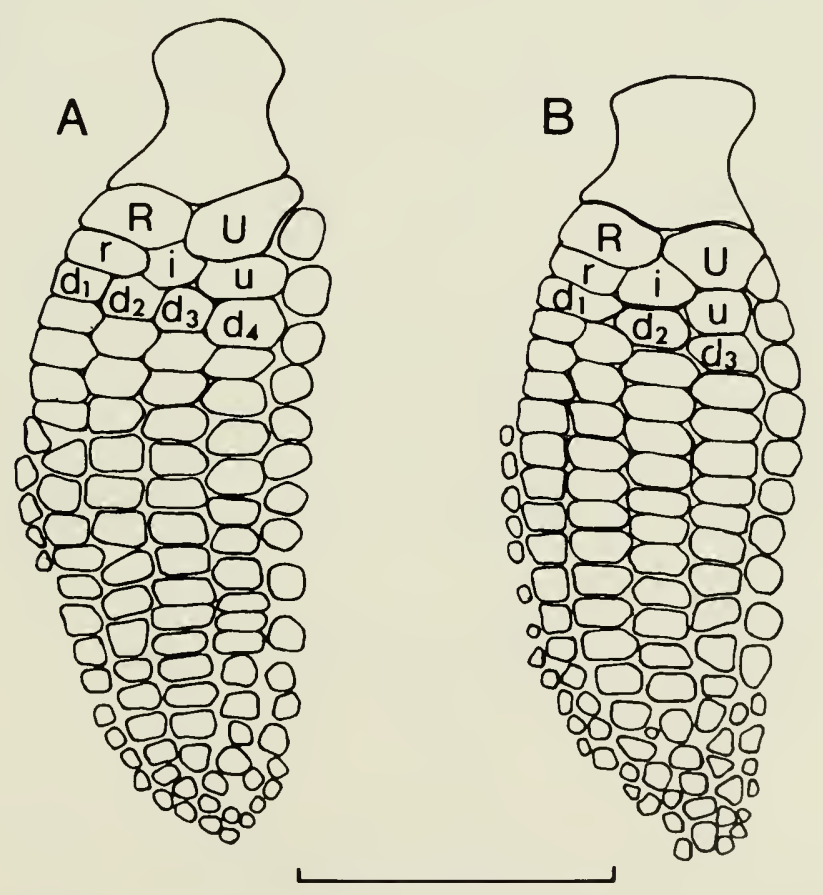

Fig. 5 Ichthyosaurus communis Conybeare, scale $=10 \mathrm{~cm}$.

Comparison of right (A) and left (B) forefins of an individual (ouM J13799) showing an extreme case of structural variability. Ventral view (for ease of comparison left fin laterally inverted). 


\section{LIMB GIRDLES}

Structure of pectoral and pelvic girdles known for a number of specimens. Pectoral girdle formed from four elements, paired coracoids, scapulae, and clavicles, and a single median interclavicle. Coracoid has anterior and posterior notches (Fig. 6A). Pelvic girdle tripartite with separate ilium, ischium, and pubis (Fig. 6B). Ilium and ischium are slender rods of bone, whereas pubis has much expanded distal and proximal heads. As girdles are frequently incomplete they are of reduced systematic interest.

\section{RIBS}

Heads of the ribs not visible in neotype, but some, exposed in BMNH 36256 , are bicipital.

\section{DENTITION}

Teeth generally fairly stout, gently recurved, with fine striations on crown and coarse striations on base. Anterior teeth more slender than those near angle of jaw. Because tooth characters are variable they are of little systematic importance.

\section{Remarks}

The first description of $I$. communis is usually attributed to Conybeare's 1822 paper (Woodward and Sherborn, 1890, p. 236; Kuhn, 1934, p. 32), but the first material assigned to the species was that of "the head, with all, or nearly all, the vertebrae in place," from Lyme Regis (Conybeare, 1821, p.

A
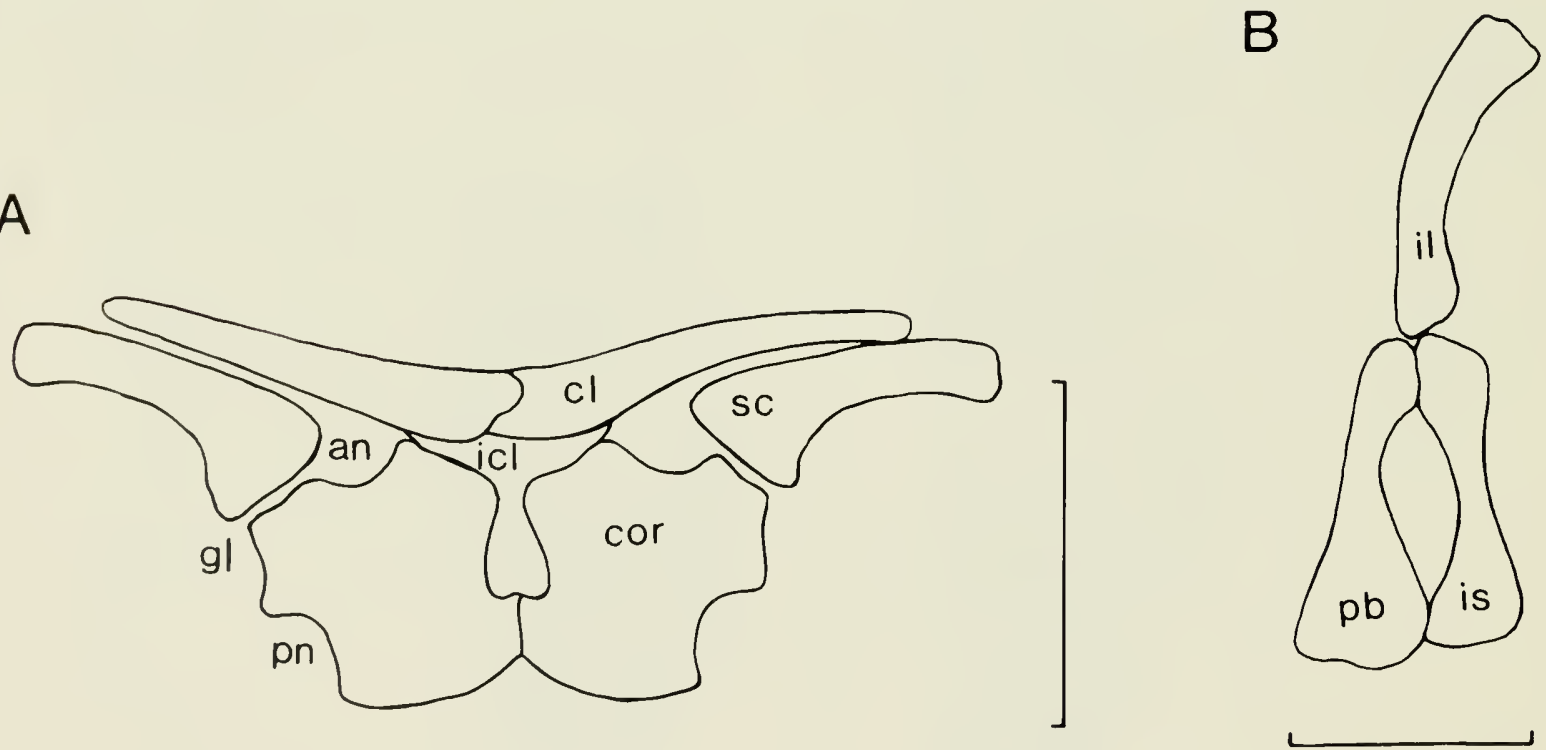

Fig. 6 Ichthyosaurus communis Conybeare, limb girdles.

A. Pectoral girdle, based upon oum J13799, scale $=10 \mathrm{~cm}$ : cl, clavicle; cor, coracoid; icl, interclavicle; sc, scapula; an, anterior notch; pn, posterior notch; gl, glenoid cavity.

B. Pelvic girdle, based upon BMNH R3372, scale $=5 \mathrm{~cm}$ : il, ilium; is, ischium; pb, pubis. 
594). No figure was given, but sufficient information was provided to enable the specimen to be recognized. No trace of this specimen can be found, and although the description is inadequate, it is no less diagnostic than Conybeare's 1822 description. I therefore conclude that the name first became available in 1821. As the description was inadequate (so too was the 1822 description), the name $I$. communis is a nomen dubium. It is thus to be rejected, and one of the synonyms adopted, or a case made for its retention. As the name 1 . communis has been in use for a considerable time, and as the original descriptions of the synonyms were inadequate, there is a good case for retaining I. communis. Retention was accomplished above by proposing a neotype consistent with what is known of the original type material.

Ichthyosaurus latimanus Owen 1840 has usually been synonymized with I. conybeari (Woodward and Sherborn, 1890, p. 237; Lydekker, 1889, p. 53; Kuhn, 1934, p. 34), but this is incorrect. The holotype of I. latimanus was a "nearly complete but dislocated skeleton", and Owen gave a number of measurements which he compared with those taken from a specimen of I. communis (Owen 1840, p. 123). I. latimanus was said to differ from I. communis in having a relatively larger forefin and smaller skull. However, if the ratio, length of entire forefin (i.e. including humerus) to the length of the entire body (i.e. including skull), is calculated from Owen's data, the values obtained for the holotype of 1 . latimanus and for Owen's specimen of I. communis are similar ( 0.09 and 0.08 respectively). Furthermore the relative length of the forefin of I. latimanus falls within the observed range for the species I. communis. The skull of Owen's holotype of I. latimanus was relatively smaller than in the specimen of $I$. communis with which he compared it, but this discrepancy can be explained in terms of differential growth. The holotype was the larger of the two skeletons, and the head of I. communis grows with a negative allometry (McGowan, 1973). As there are no inconsistencies between Owen's type material and I. communis, it is concluded that $I$. latimanus is a synonym for $I$. communis. The type specimen of $I$. latimanus was destroyed when the Bristol Museum was bombed during the last war, but according to Lydekker $(1889$, p. 53) BMNH 1065 is a cast of this specimen. It may be noted that there are inexplicable discrepancies between the original (collected from the Lower Lias of Saltford, Somerset) and the cast. According to Owen (1840, p. 123) the original specimen possessed a forefin, but Lydekker observed (on BMNH 1065) that "the only traces of the pectoral limb are a few phalangeals". Both forefins are present in the cast today, but they do not correspond with the original measurements given by Owen, although there is good agreement elsewhere.

$\begin{array}{lcc} & \begin{array}{c}\text { Author's measurements } \\ \text { on BMNH } 1065\end{array} & \begin{array}{c}\text { Owen's measurements (1840) } \\ \text { for holotype of I. latimanus } \\ (\mathrm{cm})\end{array} \\ \text { Length of jaw } & 42 & 40 \\ \text { Length of body (minus skull) } & 164 & 165 \\ \text { Width of forefin } & 5 & 9\end{array}$

As BMNH 1065 compares closely with Owen's description of the original specimen it probably is indeed a cast of the original, but the forefin discrepancy remains unexplained. It seems that for some unknown reason the fore- 
fins were not duplicated in the original cast, but a pair of forefins have been added since Lydekker's time, either to the original cast, or perhaps to a new one.

Two populations are recognized within I. communis, one from Lyme Regis, Dorset, the other from the geologically older locality of Street, Somerset. Individuals of the geologically older population (from Somerset) tend to be larger than those from Dorset, and, as the allometric growth constant for the head relative to the body is less than one (McGowan, 1973), they have relatively smaller heads. These larger individuals have previously been referred to the species I. intermedius, and Von Huene (1922, p. 9) regarded the possession of a relatively smaller head as a diagnostic character of the species. Other differences between the two populations include minor variations in the skull and forefin, and in both instances the geologically older individuals are the more primitive (for a discussion of evolutionary trends in ichthyosaurs see McGowan, 1972b). Thus individuals from Somerset tend to have relatively smaller orbits and larger maxillae, but these differences are not statistically significant. More striking is the variation in forefin structure: in the older population the number of elements in the longest digit does not exceed 20, there are no more than five primary digits, and notching almost always occurs in at least one or two elements. Notching never occurs in the Dorset material, the number of primary digits exceeds five, and the number of elements in the longest digit exceeds 20 .

The temporal separation between these two localities is represented by the ammonite zone of Psiloceras planorbis, which reaches a maximum thickness of 30 metres in Somerset (Arkell, 1933, p. 122). While any estimate of sedimentation rate in the Lower Lias would be speculative, some indication of the temporal separation represented by these 30 metres of shales and limestones can be obtained by reference to other neritic marine deposits for which radiometric data are available. The rates of deposition in the shallow epeiric sea which covered much of North America during the Cretaceous vary from 344 feet $(105 \mathrm{~m})$ per million years for the Pierre Shale in Wyoming (Gill and Cobban, 1966) through 256 feet $(78 \mathrm{~m}$ ) per million for the Bearpaw Formation of Southern Saskatchewan (Caldwell, 1968) to 150 feet $(46 \mathrm{~m})$ per million years in Alberta for the interval Middle Albian to Upper Maestrichtian (Folinsbee et al., 1961). If similar deposition rates could be assumed for the English Liassic deposits, which were similarly laid down in a shallow (though not epicontinental) sea, the temporal separation between the Dorset and Somerset localities would lie somewhere between 0.3 and 0.7 million years.

As the differences between the two populations are small and as the temporal separation probably did not amount to more than half a million years, it seems prudent to treat them as part of an evolutionary continuum not worthy of taxonomic distinction.

\section{Ichthyosaurus breviceps Owen Figs. 7-8}

Ichthyosaurus breviceps Owen, 1881, p. 109, pl. 29, fig. 2. Ichthyosaurus breviceps Owen, Lydekker, 1888, p. 311. 

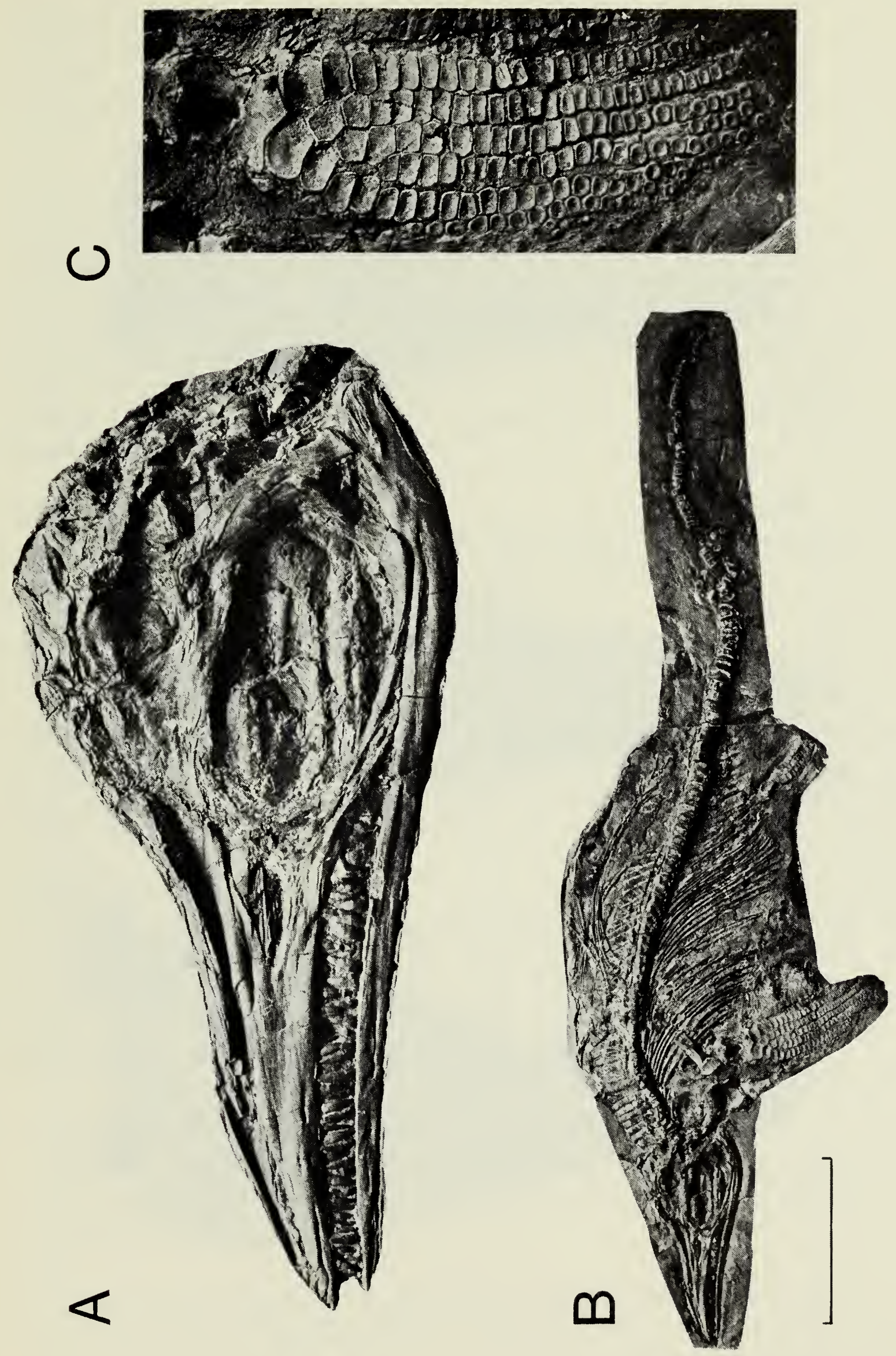

Fig. 7 Ichthyosaurus breviceps Owen, scale $=20 \mathrm{~cm}$.

BMNH 43006, holotype, Lower Lias, Lyme Regis.
A. Skull.
B. Entire specimen.
C. Forefin, left dorsal view. 

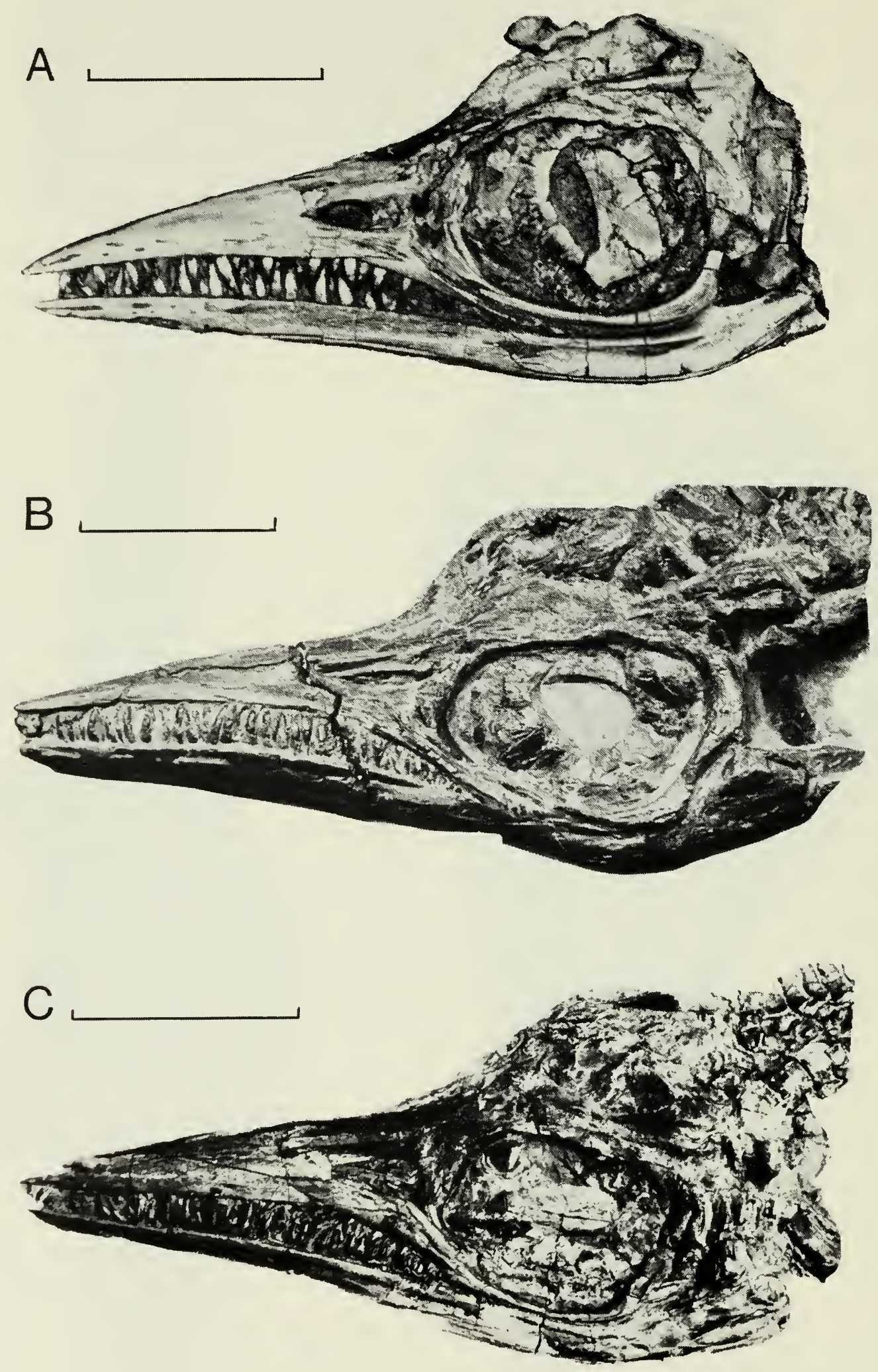

Fig. 8 Ichthyosaurus breviceps Owen, scale $=6 \mathrm{~cm}$.

A. BMNH 39263, entire (photograph laterally inverted), Lower Lias, Lyme Regis.

в. BMNH R3367, skull, Lower Lias, Lyme Regis.

C. BMNH R216, skull, Lower Lias, Lyme Regis. 
Ichthyosaurus breviceps Owen, Mansell-Pleydell, 1888, p. 19.

Ichthyosaurus breviceps Owen, Lydekker, 1889, p. 52.

Eurypterygius breviceps (Owen), Von Huene, 1922, p. 8, pl. 1, fig. 1, fig. 2. [non] Ichthyosaurus breviceps Owen, 1881, pl. 29, fig. 1.

[non] Eurypterygius breviceps (Owen), Von Huene, 1922, pl. 1, fig. 3.

\section{Emended Diagnosis}

Vertebral count to tail bend $68 \pm 2$; vertebral count to pelvis $<46$; ratio, diameter of orbit to length of jaw $>0.25$; ratio, length of snout to length of jaw $<0.57$; ratio, length of premaxillary segment to length of jaw $0.33-$ 0.44 , but frequently $<0.40$; ratio, length of prenarial segment to length of jaw usually $<0.43$; ratio internal diameter of sclerotic ring to diameter of orbit $>0.35$; maxillary teeth probably $\geqslant 10$; primary digits $\geqslant 5$; elements in longest digit probably $>25$; notching probably does not occur in fore- or hindfin elements.

\section{Holotype}

BMNH 43006, a complete skeleton in the British Museum (Natural History), London, described and figured by Owen (1881, p. 109, pl. 29).

\section{Other Material}

The following specimens have contributed to the emended description: BMNH R216, вMNH 8437, вMNH R1074, вмNH R3367, вмNH 39263 and BMNH 33277. The first three specimens are complete or nearly complete skeletons, the fourth is a skull and partial pectoral girdle with some vertebrae and ribs, the fifth a particularly well-preserved skull, and the sixth is a partial skull with incomplete post-cranial skeleton.

\section{Locality and Horizon}

With the exception of BMNH 8437, for which no information is available, all material examined was collected from Lyme Regis, Dorset. Owen (1881) states that the species has been found in the neighbourhood of Brownish, Somerset, from the zone of Arietites bucklandi. I. breviceps therefore occurs in the upper portion of the Blue Lias, from the zone of Schlotheimia angulata to that of Arnioceras semicostatum (Upper Hettangian - Lower Sinemurian).

\section{Emended Description}

I. breviceps was a small species reaching a maximum length of about $1.5 \mathrm{~m}$. It was uncommon, and, to date, only seven specimens have been positively identified.

SKULL

Reduced snout and large orbit clearly differentiates this species from I. communis and all other latipinnates. Ratios, diameter of orbit to length of jaw, and length of snout to length of jaw 0.31 and 0.55 respectively in holotype (mean values $0.30,0.53$ ). Brevity of snout accentuates downward curvature giving strikingly avian appearance (Figs. 7, 8). Ratio, length of premaxillary segment to length of jaw 0.44 in holotype, mean 0.39 . External naris tends to be relatively larger than in 1 . communis: ratio, length of external naris to diameter of orbit 0.36 in holotype, mean value 0.38 . 
FOREFIN

Structure of forefin known in holotype, in BMNH 8437, and in BMNH R216. Primary digits number between five (holotype) and six (BMNH R216), total digital count between eight and nine. Number of elements in longest digit 27 in both holotype and BMNH 8437. No notching in fore- or hindfin elements.

AXIAL SKELETON

Vertebral count to tail bend, indeterminate in holotype, is 69 or 70 in BMNH 8437, and estimates for BMNH R216 and BMNH 1074 are 67, and 65 to 67, respectively. Total vertebral count approximately 116 for holotype, 122 for BMNH R216 (mean value 135 in I. communis).

\section{LIMB GIRDLES}

Because of poor preservation or exposure, structure of girdles is not well known. In holotype pectoral girdle is represented by two poorly preserved scapulae and part of a clavicle. Pelvic girdle indeterminate.

RIBS

Rib heads obscured in holotype, but those exposed in BMNH 33277 and BMNH R1074 are bicipital. In BMNH R216 rib heads are again obscured, but double rib facets can be seen on a number of centra.

\section{DENTITION}

Teeth of holotype have smooth bases, with fine striations on crown. Shape similar to those of $I$. communis.

\section{Remarks}

Owen included BMNH R1157 in his original description of 1 . breviceps, but this specimen is a longipinnate and is described elsewhere as a new species (McGowan, 1974). BMNH 2001 might belong to the present species, but the skull is so broken and distorted that no measurements can be made and the specimen must remain unidentified. This specimen is of historic interest because it was figured by Hawkins $(1834, \mathrm{pl} .6)$ as the type of Ichthyosaurus chiropolyostinus. If this specimen were referred to 1 . breviceps it would extend the upper limit of the size range by about 20 per cent.

\section{Ichthyosaurus conybeari Lydekker}

Figs. 9-10

Ichthyosaurus conybeari Lydekker, 1888, p. 312.

Ichthyosaurus conybeari Lydekker, Lydekker, 1889, p. 53, fig. 22.

Eurypterygius conybeari (Lydekker), Von Huene, 1922, p. 8, pl. 13, fig. 9.

\section{Emended Diagnosis}

Vertebral count to tail bend 79; vertebral count to pelvis $<46$; ratio, diameter of orbit to length of jaw probably $<0.25$; ratio, length of snout to length of jaw $>0.57$; ratio, length of premaxillary segment to length of jaw 


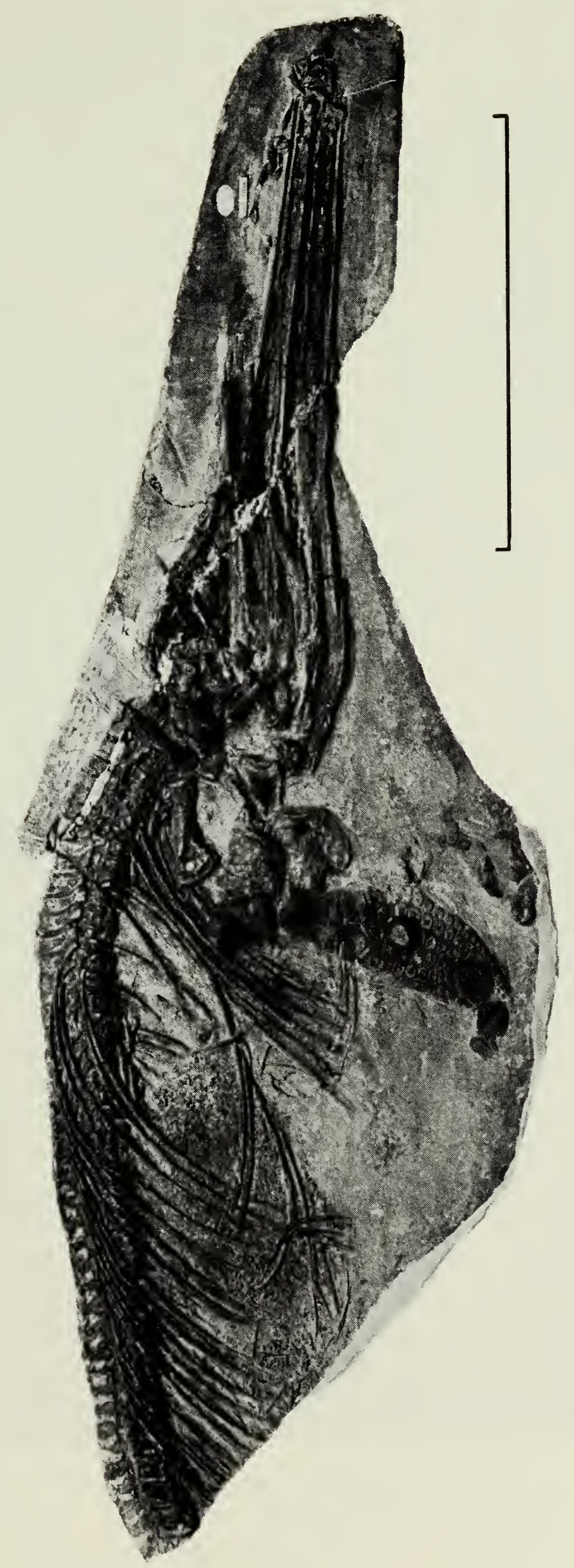

Fig. 9 Ichthyosaurus conybeari Lydekker, scale $=20 \mathrm{~cm}$. BMNH 38523, holotype, Lower Lias, Lyme Regis. 


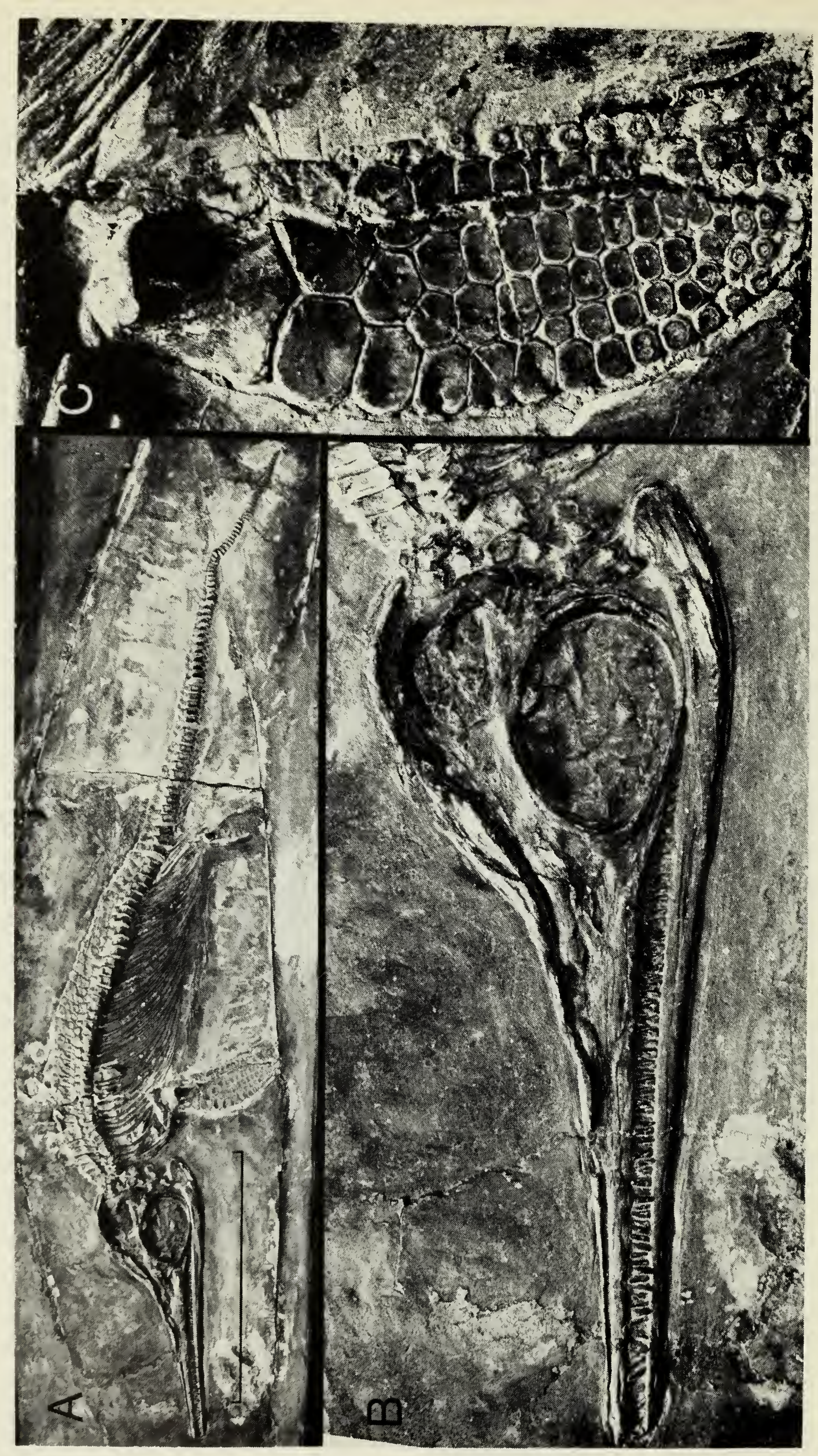

Fig. 10 Ichthyosaurus conybeari Lydekker, scale $=20 \mathrm{~cm}$. IGS 956, Lower Lias, Lyme Regis.

A. Entire specimen.

B. Skull.

C. Forefin, left dorsal view.

Crown Copyright Geological Survey photograph.

Reproduced by permission of the Controller, Her Majesty's Stationery Office. 
probably $>0.40$; ratio, length of prenarial segment to length of jaw probably $>0.43$; ratio, internal diameter of sclerotic ring to diameter of orbit $>0.35$; maxillary teeth $>18$; primary digits probably 5 ; elements in longest digit $<25$; notching occurs in forefin elements.

\section{Holotype}

BMNH 38523, a poorly preserved and incomplete skeleton, comprising skull, forefin, pectoral girdle, and partial axial skeleton, in the British Museum (Natural History), London.

\section{Other Material}

IGS 956, a complete and well-preserved skeleton in the Institute of Geological Sciences, London.

\section{Locality and Horizon}

Both specimens were collected from Lyme Regis, Dorsetshire, and the geological range of the species is taken to be from the zone of Schlotheimia angulata to Arnioceras semicostatum (Upper Hettangian - Lower Sinemurian: Fig. 4).

\section{Emended Description}

I. conybeari, with but two known representatives, is the rarest Liassic latipinnate. Based upon a single complete specimen (IGS 956), with total length of only $87 \mathrm{~cm}$, it appears to be a small species, but this might be an immature individual. The larger specimen (BMNH 38523) has jaw length comparable with $I$. communis, but exceeds range for I. breviceps (see Fig. 1). I. conybeari differs significantly from $I$. breviceps (Table 2 ) in having a relatively smaller orbit, longer snout, and prenarial and premaxillary regions, and in possessing notched forefin elements. Only significant differences from 1 . communis are lower vertebral count to pelvis and higher maxillary tooth count. Forefin relatively smaller compared with body length than in $I$. communis but not statistically significant. However, in contrast to specimens of $I$. communis from same locality (Lyme Regis) as I. conybeari, forefin has notched elements and number of elements in the longest digit does not exceed 20. For these reasons $I$. conybeari is considered to be a distinct species from I. breviceps and I. communis.

I. conybeari, with its long and slender snout bears a superficial resemblance to I. tenuirostris, and its smaller size might suggest it was merely a juvenile form of $I$. tenuirostris. There are, however, mutually exclusive values in certain discontinuous variates. The vertebral count to the pelvis, 40 in I. conybeari, is significantly lower than in I. communis (Table 2), which in turn is significantly lower than in I. tenuirostris. Furthermore the primary and total digital counts, and the maximum number of elements in the longest digit are all higher in I. conybeari than in I. tenuirostris (Table 1). Small sample sizes prevent a statistical treatment, but it seems that there were probably significant differences in some continuous variates. Thus the ratios, length of snout to length of jaw, length of premaxillary segment to length of jaw, and length of prenarial segment to length of jaw are all much lower in 
I. conybeari than in I. tenuirostris. There can therefore be little doubt that they are distinct species.

\section{SKULL}

Because of poor preservation of holotype most information has been obtained from IGS 956. Holotype skull appears very long compared with rest of body, and snout is long and slender but cannot be measured accurately. In IGs 956 ratio, length of snout to length of jaw is 0.65 , which exceeds most specimens of $I$. communis. Snout and lower jaw, both very slender, taper to point. Orbit appears relatively large but ratio, diameter of orbit to length of jaw only 0.23. Aperture of sclerotic ring, probably distorted, is elliptical, and ratio, internal diameter of sclerotic ring to diameter of orbit is 0.40 , comparable with I. communis and I. breviceps. Maxilla, slender and splint-like, tapers to sharp point anteriorly and bears 21 teeth. Ratio, length of premaxillary segment to length of jaw 0.47 , which exceeds most specimens of I. communis. External narial aperture set well back: ratio, length of prenarial segment to length of jaw 0.53 , exceeding that of most specimens of $I$. communis.

\section{FOREFIN}

In both holotype and IGs 956 forefin has five primary digits, one accessory, with 19 elements in longest digit. Notching occurs in both specimens in at least two elements of first digit. Forefin relatively small compared with body length.

\section{HINDFIN}

Hindfin, well preserved in IGS 956, has five primary digits and one post-axial accessory digit. Anterior margin of tibia emarginated, no indication of notching elsewhere.

\section{AXIAL SKELETON}

Vertebral count to tail bend 79 in IGS 956. (Indeterminate in holotype.)

\section{LIMB GIRDLES}

Type specimen with a pair of well-preserved coracoids and a scapula, but pectoral girdle largely indeterminate in IGS 956. Width of coracoid less than anterior-posterior length. Anterior and posterior notches present, former approximately $\frac{1}{7}$ width of coracoid. Scapula of moderate size, maximum width almost half length. Clavicle gently curved and fairly stout. Only one small slender pelvic element (possibly the ilium) well exposed, somewhat less than length of femur.

RIBS

Exposed ribheads (in holotype) bicipital.

\section{DENTITION}

Teeth fairly stout recurved cones with smooth bases and finely striated crowns, much like those of $I$. breviceps. Teeth much more slender towards tip of snout than at angle of jaw. 

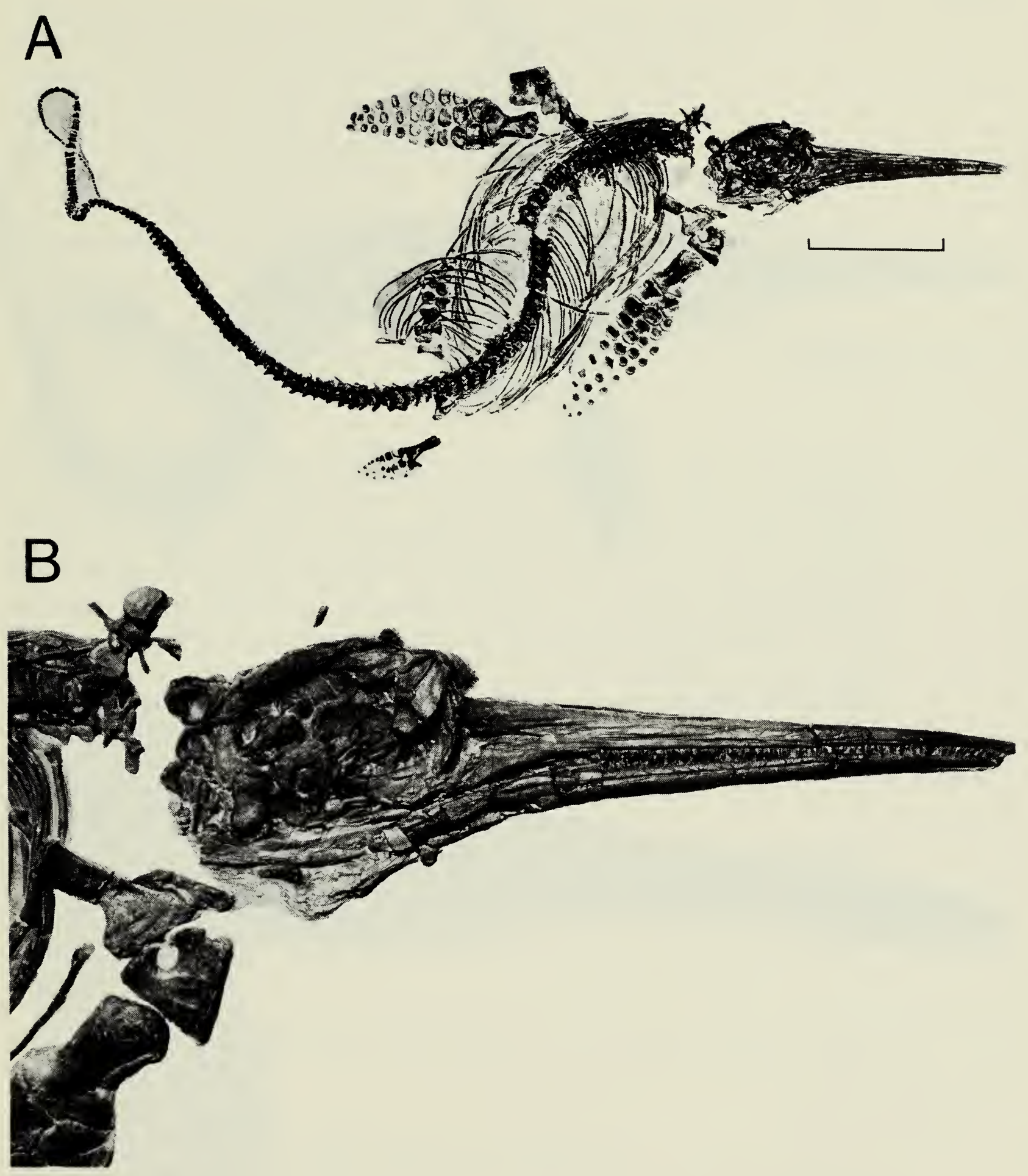

Fig. 11 Ichthyosaurus tenuirostris Conybeare, scale $=25 \mathrm{~cm}$. IGS 51236, proposed neotype, Lower Lias, Street.

A. Entire specimen.

B. Skull and pectoral girdle.

Crown Copyright Geological Survey photograph.

Reproduced by permission of the Controller, Her Majesty's Stationery Office. 

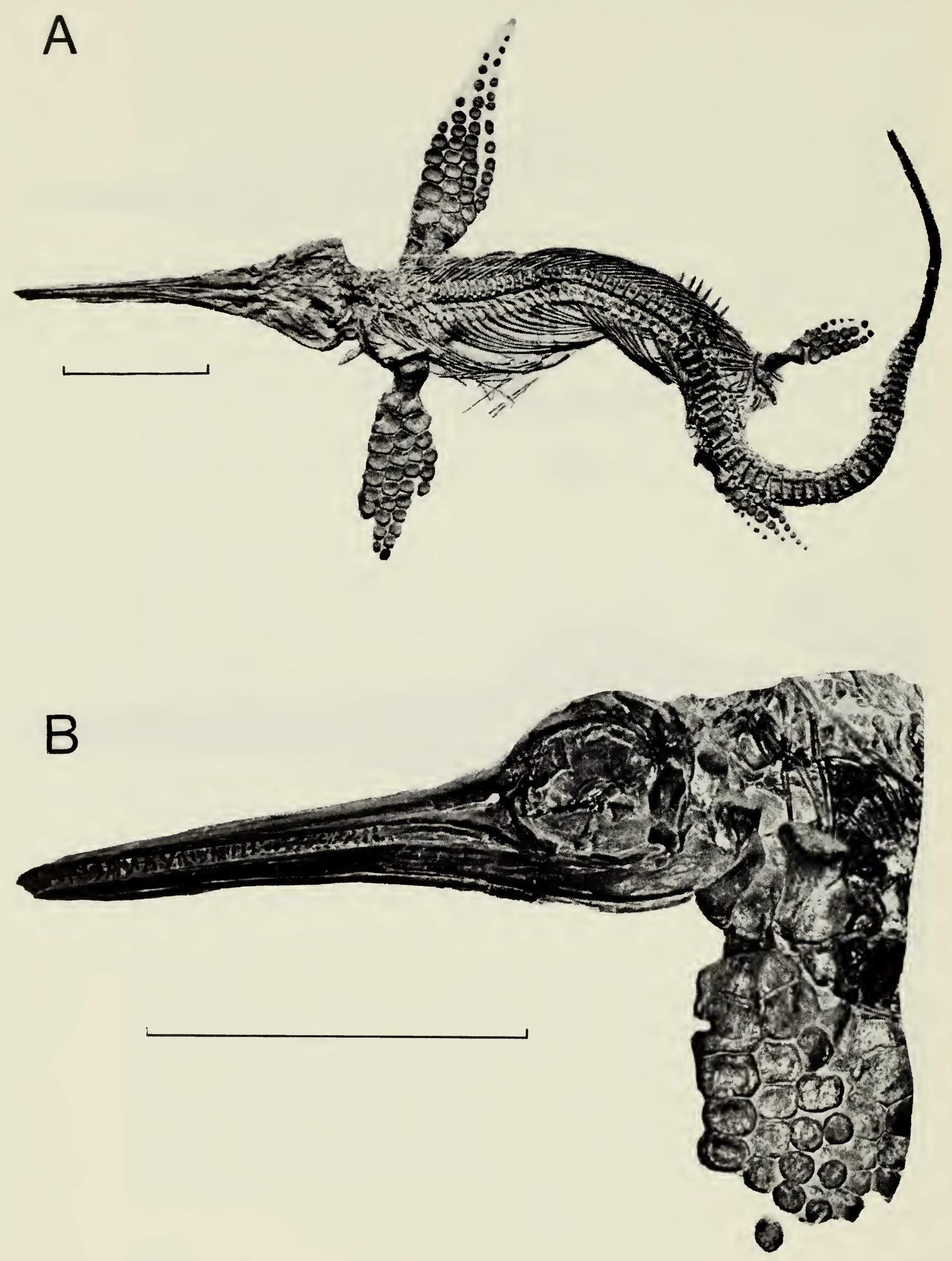

Fig. 12 Ichthyosaurus tenuirostris Conybeare, scale $=15 \mathrm{~cm}$.

A. BMNH R498, Lower Lias, Street.

B. оUм J10305, Lower Lias, Street. 


\section{Ichthyosaurus tenuirostris Conybeare}

Figs. 11-12

Ichthyosaurus tenuirostris Conybeare, 1822, p. 108, pl. 15, fig. 10.

Ichthyosaurus tenuirostris Conybeare, De la Beche, 1826, p. 27.

Ichthyosaurus chirostrongulostinus Hawkins, 1834, pl. 13.

Ichthyosaurus chirostrongulostinus Hawkins, 1840, pl. 13.

Ichthyosaurus tenuirostris Conybeare, Owen, 1840, p. 117.

Ichthyosaurus tenuirostris Conybeare, Owen, 1881, p. 122, pl. 24, fig. 8; pl. 25, fig. 3; pl. 32, figs. 1-6.

Ichthyosaurus tenuirostris Conybeare, Mansell-Pleydell, 1888, p. 19.

Ichthyosaurus tenuirostris Conybeare, Lydekker, 1888, p. 311.

Ichthyosaurus tenuirostris Conybeare, Lydekker, 1889, p. 83, fig. 25.

Leptopterygius tenuirostris (Conybeare), Von Huene, 1922, p. 11, pl. 2, fig. 1, fig. 3.

\section{Emended Diagnosis}

Vertebral count to tail bend $>79$; vertebral count to pelvis $\geqslant 46$; ratio, diameter of orbit to length of jaw $<0.25$; ratio, length of snout to length of jaw $>0.70$; ratio, length of premaxillary segment to length of jaw $>0.48$; ratio, length of prenarial segment to length of jaw $>0.56$; ratio, internal diameter of sclerotic ring to diameter of orbit $>0.35$; teeth predominantly slender; 4 primary digits in forefin; elements in longest digit probably $<17$; radius notched; humerus with constricted shaft and expanded distal head; occlusal edges of radius and ulna may enclose small foramen; individual forefin elements relatively large, few in number, well spaced towards apex of fin; femur with slender shaft and wide distal head; tibia and tibiale notched.

\section{Original Type-Material}

A tooth figured by Conybeare (1822, pl. 15, fig. 10) which was in the collection of the Geological Society (Woodward and Sherborn, 1890, p. 240) but which now appears lost (Delair, 1960, p. 70).

\section{Proposed Neotype}

IGS 51236, a complete skeleton in the Institute of Geological Sciences, London (Fig. 11).

\section{Consistency of Neotype with Original Type-Material}

The long slender snout is consistent with Conybeare's description (1822, p. 108 ), and many of the teeth correspond in general shape to original type specimen.

\section{Other Material}

BMNH R498, an entire and well-preserved specimen, ouM J10305, a partial skeleton, and SCM 8372, a complete skeleton.

\section{Locality and Horizon}

The original description did not give the type locality. The proposed neotype, OUM J10305, BMNH R498, and SCM 8372 were all collected from Street in 
Somerset and are therefore probably from the Pre-planorbis beds. Lydekker (1889, pp. 83-88) listed a number of specimens of I. tenuirostris from Lyme Regis, but these are largely fragmentary and cannot definitely be assigned to this taxon. The same is true of specimen BMNH 36876 which was collected from the Upper Lias of Whitby. Specimen BMNH R1120, figured by Owen (1881, pl. 32, fig. 1) is probably a member of the present species and is referred to by Lydekker $(1889$, p. 83 ) as being, "probably from the Lower Lias of Lyme Regis". It is therefore concluded that this species is probably from the lowermost beds of the Lower Lias, but the possibility that it extended further up into the Lower Lias cannot be excluded. The range will therefore be taken as extending from the Pre-planorbis beds, possibly to the zone of Echioceras raricostatum (Lower Hettangian - Upper Sinemurian[?]).

\section{Description of Neotype and Other Material}

I. tenuirostris is not an uncommon ichthyosaur but as there are so few complete specimens it is not a very well-known species. It was probably somewhat larger than $I$. communis, reaching a maximum length of about three metres.

SKULI

Snout and lower jaw extremely slender; ratio, length of snout to length of jaw 0.72 in neotype, 0.73 in OUM $\mathrm{J} 10305$, and approximately 0.76 in BMNH R498. Orbit occupies much of post-rostral portion of skull, but, as snout is very long, orbit small relative to length of skull; ratio, diameter of orbit to length of jaw approximately 0.23 in neotype, 0.22 in ouM J10305. Ratio, internal diameter of sclerotic ring to diameter of orbit 0.41 (ouM J10305). Small size of maxilla reflected in large value for ratio, length of premaxillary segment to length of jaw 0.52 in neotype and in oum J10305. Ratio, length of external naris to diameter of orbit 0.44 in oum $\mathrm{J} 10305$, probably 0.37 in. neotype (mean value 0.38 in both $I$. communis and 1 . breviceps). Ratio, length of prenarial segment to length of jaw 0.60 in neotype, 0.61 in oum J10305. Forty-four teeth in upper jaw of oum J10305, but uncertainty regarding possession of maxillary teeth; skull figured by Owen (1881, pl. 32, fig. 2) appears to have them.

\section{FOREFIN}

Four primary but no accessory digits, maximum number of elements in longest digit, 15 in BMNH R498, may not exceed 16. Individual elements rounded, relatively large, few in number, well spaced distally. Small foramen enclosed between radius and ulna in ouM J10305 and third and fourth distal carpals fused in left fin. Lydekker $(1889$, p. 83) noted that radius and ulna frequently ankylose. Distal head of humerus much expanded giving a constricted appearance to midshaft region. Forefins unreliable in neotype as they have been reconstructed distally.

\section{HINDFIN}

Hindfin with only three digits; tibia and tibiale emarginated. Femur slender with expanded distal head. 
Vertebral count to tail bend 85 in ouM J10305, 79 or 80 in SCM 8372 . In neotype and BMNH R498 the character is largely indeterminate but there is evidence of constrictions at 84th and 85th vertebrae respectively, probably marking position of tail bend. Vertebral count to pelvis 47 in neotype, 49 or 50 in BMNH R498.

\section{LIMB GIRDLES}

Girdles largely obscured in BMNH R498 and oum J10305, but well exposed in neotype where coracoids are rectilinear rather than rounded in outline and with single (anterior) notch.

\section{DENTITION}

Many teeth slender, others relatively stout recurved cones resembling those seen in other species.

\section{Remarks}

I. tenuirostris has hitherto been referred to the longipinnates (Lydekker 1889 , Von Huene 1922, Kuhn 1934), but it probably has greater affinity with the latipinnates. One of the major problems in resolving its true affinity has been the interpretation of the forefin. In BMNH R498 the forefin has an overall longipinnate appearance (McGowan 1972a) in that there are only 15 elements in the longest digit, the radius is notched, and the individual elements are relatively large and well spaced distally. It is difficult to determine the number of primary digits; in the left forefin the fourth digit appears to be an accessory digit, originating from the lateral margin of the third distal carpal, having little or no contact with the ulnare. Conversely, in the right forefin, the fourth digit originates from a distinct facet on the ulnare and is, by definition, a primary digit. Thus there are three primary digits in the left forefin and four in the right. A similar situation is apparent in IGS 51236 where the left forefin has four primary digits and the right, three primary and one post-axial accessory digits. In a third specimen, oum J10305, the fins are incomplete but the left fin has four primary digits. These different digital counts can be reconciled if it is assumed that there are four primary digits and that the articulation of the fourth digit (with the ulnare) is not always well developed.

Corroborative evidence for the latipinnate status of $I$. tenuirostris is available from the skull. In oum $\mathrm{J} 10305$ the ratio, diameter of orbit to length of jaw is 0.22 , the ratio, internal diameter of sclerotic ring to diameter of orbit is 0.41 , and the ratio, length of premaxillary segment to the length of jaw is 0.52 (also 0.52 in neotype). All of these values lie well within the predicted range for Lower Liassic latipinnates (McGowan, 1972a, p. 7). It is therefore concluded that I. tenuirostris is a latipinnate.

The original description of $I$. tenuirostris, although somewhat inadequate, did include reference to the long snout, "... the species is best marked by the extreme length and thinness of the snout, in which points it very strikingly exceeds all the other ichthyosauri" (Conybeare, 1822, p. 108); and I consider this to be a valid description. 


\section{Conclusions}

The latipinnate ichthyosaurs of the English Lower Lias, which far outnumber their longipinnate contemporaries, are represented by four species: Ichthyosaurus communis, I. breviceps, I. conybeari, and I. tenuirostris. I. communis, the most common species, accounts for about half of the ichthyosaurs found in England. Most specimens referred to 1. communis were collected from Lyme Regis, Dorset (Upper Hettangian - Lower Sinemurian) and can be distinguished from the geologically older population collected from Street, Somerset (Lower Hettangian). I. communis was a medium-sized species reaching a maximum length of about $2.5 \mathrm{~m}$ though most specimens are less than $2 \mathrm{~m}$. I. communis is similar in size and general proportions to the German longipinnate Stenopterygius quadriscissus, the most common Upper Liassic species. Latipinnates are not found in the Upper Lias and perhaps S. quadriscissus was a faunal replacement for I. communis.

I. breviceps is not a common species, and only seven specimens are known to date, all of which were collected from Lyme Regis. It is much smaller than I. communis, the maximum length being about $1.5 \mathrm{~m}$. The species is characterized by the abbreviated snout and large orbit.

I. conybeari is rare, with only two known specimens, both from Lyme Regis. Like I. breviceps this was probably a small species, the larger of the two individuals having an estimated body length of less than $1.5 \mathrm{~m}$. The species is characterized by its long thin snout and relatively small forefins.

Although I. tenuirostris is represented by only four complete skeletons, a number of isolated epipodials are known and it would seem that it was not an uncommon species. Slightly larger than $I$. communis, the maximum body length was about $3 \mathrm{~m}$. The species is characterized by its remarkably long, thin snout.

The Lower Liassic latipinnates were thus small to medium-sized ichthyosaurs, and far outnumbered their larger longipinnate contemporaries (McGowan, 1974). It may not have been through some caprice of the fossil record that latipinnates outnumber longipinnates in the Lower Lias. Longipinnates may have occupied a different ecological niche, they may have been oceanic rather than neritic, solitary rather than gregarious; or their large size may have produced lower population densities. The success of the latipinnates during that early part of the Jurassic is measured in the great wealth of material which they left behind. It is therefore somewhat surprising that nothing more is seen of latipinnates until the Upper Jurassic where Ophthalmosaurus occurs. Perhaps this gap is a reflection of a failure of the fossil record rather than of the latipinnates, and only further material can answer this question.

\section{Acknowledgments}

I wish to express my sincere thanks for the help and hospitality I received from the staffs of the many institutions visited. I particularly wish to thank Dr. Alan Charig, Mr. Cyril Walker, Miss Marilyn Holloway and Mr. Philip Palmer of the British Museum (Natural History); Dr. Colin Forbes of the 
Sedgwick Museum and Mr. Peter Biddlestone formerly of the Sedgwick Museum, Cambridge, and of the Royal Ontario Museum; Dr. Ivimey-Cook, and Mr. Martin Pulsford of the Institute of Geological Sciences, London; Mr. Andrew Mathieson and Mr. M. J. Jones of the Leicester County Museum, and the staff of the Clarks Shoe Museum, Street, Somerset. Figures 10 and 11 were kindly provided by the Institute of Geological Sciences, London.

I thank Mrs. Janet Clarke and Mrs. Lynda Spicer, RoM, for their secretarial help; Mrs. Sophie Poray, RoM, for the drawings; Mr. Leighton Warren, Photography Department, ROM, for photographs; Mrs. Erica Wolfe, ROM, for German translations and Miss E. Dowie of the ROM Library for assistance with literature searches. For reading the manuscript and making many helpful suggestions I thank Dr. Allan Baker of the Department of Ornithology, ROM, Dr. R. V. Melville of the Institute of Geological Sciences, London, and Dr. C. S. Churcher of the University of Toronto.

\section{Literature Cited}

ARKELL, W. J.

1933 The Jurassic System in Great Britain. Oxford, Clarendon Press. 681 pp.

BONAPARTE, C. L.

1841 A new systematic arrangement of vertebrated animals. Trans. Linn. Soc. Lond., vol. 18, pt. 4, pp. 247-304.

CALDWELl, W. G. E.

1968 The Late Cretaceous Bearpaw Formation in the South Saskatchewan River Valley. Rep. Sask. Res. Coun., no. 8, pp. 1-89.

CONYBEARE, W. D.

1822 Additional notices on the fossil genera Ichthyosaurus and Plesiosaurus. Trans. Geol. Soc. Lond., ser. 2, vol. 1, no. 1, pp. 103-123.

DE LA BECHE, H. T.

1826 On the Lias of the Coast, in the vicinity of Lyme Regis, Dorset. Trans. Geol. Soc. Lond., ser. 2, vol. 2, no. 1, pp. 21-30.

DE LA BECHE, H. T. AND W. D. CONYBEARE

1821 Notice of the discovery of a new fossil animal, forming a link between the Ichthyosaurus and the crocodile, together with general remarks on the osteology of the Ichthyosaurus. Trans. Geol. Soc. Lond., ser. 1, vol. 5, no. 2, pp. 559-594.

DELAIR, J. B.

1960 The Mesozoic reptiles of Dorset (Part III: conclusion). Proc. Dorset Nat. Hist. Archaeol. Soc., vol. 81, pp. 59-85.

FOLINSBEE, R. E., H. BAADSGAARD AND J. LIPSON

1961 Potassium-argon dates of Upper Cretaceous ash falls, Alberta, Canada. Ann. N.Y. Acad. Sci., vol. 91, pp. 352-359.

GILL, J. R. AND W. A. COBBAN

1966 The Red Bird section of the Upper Cretaceous Pierre Shale in Wyoming. Prof. Pap. U.S. Geol. Surv., 73 pp.

HAWKINS, T.

1834 Memoirs of Ichthyosauri and Plesiosauri, extinct monsters of the ancient earth. London, Rolfe and Fletcher. 58 pp. 
1840 The book of the great sea-dragons, Ichthyosauri and Plesiosauri ... gedolim taninim, of Moses. Extinct monsters of the ancient Earth. London, W. Pickering. 27 pp.

HUENE, F. VON

1922 Die Ichthyosaurier des Lias und ihre Zusammenhänge. Monogrn. Geol. Paläont., Ser. 1, Heft 1, pp. 1-114.

1948 Short review of the lower tetrapods.

In Du Toit A. L., ed. Robert Broom commemorative volume Royal Society of South Africa special publication. Capetown, Published by the Society, pp. 65-106.

KOENIG, C. D. E.

1818 Synopsis of the Contents of the British Museum. Edit. 13, p. 54.

KUHN, o.

1934 Ichthyosauria. In Quenstedt, W., ed. Fossilium Catalogus. 1: Animalia. Pars 63. Berlin, Junk, pp. 1-75.

LYDEKKER, R.

1888 Note on the classification of the Ichthyopterygia with a notice of two new species. Geol. Mag., vol. 3, pp. 309-314.

1889 Catalogue of the fossil Reptilia and Amphibia in the British Museum (Natural History). Part II. Containing the orders Ichthyopterygia and Sauropterygia. London, Printed by Order of the Trustees of the British Museum. 307 pp.

MANSELL-PLEYDELL, J. C.

1888 The reptiles of Dorset. Pros. Dorset Nat. Hist. Antiq. Fld. Club, vol. 9, pp. $1-40$.

MCGOWAN, C.

1972a The distinction between latipinnate and longipinnate ichthyosaurs. Life Sci. Occ. Pap., R. Ont. Mus., no. 20, pp. 1-8.

$1972 \mathrm{~b}$ Evolutionary trends in longipinnate ichthyosaurs with particular reference to the skull and fore fin. Life Sci. Contr., R. Ont. Mus., no. 83, pp. 1-38.

1973 Differential growth in three ichthyosaurs: Ichthyosaurus communis, 1 . breviceps, and Stenopterygius quadriscissus (Reptilia, Ichthyosauria). Life Sci. Contr., R. Ont. Mus., no. 93, pp. 1-24.

1974 A revision of the longipinnate ichthyosaurs of the Lower Jurassic of England, with descriptions of two new species (Reptilia, Ichthyosauria). Life Sci. Contr. 97, R. Ont. Mus.

OWEN, R.

1840 Report on the British fossil reptiles. Part 1. Rep. Br. Ass. Advmt. Sci., vol. 9, pp. 43-126.

1881 A monograph of the fossil Reptilia of the Liassic formations. Plesiosaurus, Dimorphodon, and Ichthyosaurus. [Part III] Order Ichthyopterygia ... Ichthyosaurus. Palaeontogr. Soc. [Monog.] 35, pp. 83-134.

SIMPSON, G. G., A. ROE, AND R. C. LEWONTIN

1960 Quantitative zoology. Rev. ed. New York, Harcourt, Brace. 440 pp.

SOKAL, R. R. AND F. J. ROHLF

1969 Biometry; the principles and practice of statistics in biological research. San Francisco, Freeman, 776 pp.

WOODWARD, A. S. AND C. D. SHERBORN

1890 A catalogue of British fossil Vertebrata. London, Dulau. 396 pp. 

